\title{
Strategy Typology in Turbulent Environment: Cases from the Korean Exporting Organizations
}

\author{
Jihwan Yum $^{1^{*}}$ \\ ${ }^{1}$ School of Business Administration, Hanyang Cyber University

\section{혼란한 환경 하에서의 전략 구분에 따른 전략적 선택과 성과: 한국 수출기업의 경우를 중심으로} \\ 염지환 ${ }^{*}$ \\ ${ }^{1}$ 한양사이버대학교 경영학부
}

\begin{abstract}
The study revisits Miles and Snow's strategy typology to investigate the performance relationship with the strategic behavior. Where the most strategy typology researches discern the typology by the respondent's survey such as choosing the best representative behavior for the organization, we developed the strategic typology by the organization's behavior such as marketing strategy, research and development strategy and members' attitudes to the quality. The financial crisis in Korea has reestablished organizational behavior. The study emphasized the changing attitudes of strategy. The results demonstrate that prospector organizations outperform other strategic behavior organizations.
\end{abstract}

요 약 본 연구는 Miles 와 Snow 교수의 전략 분류 기법을 국내 수출 기업들에 적용하여 기업 성과와의 관련성을 측정하였다. 대부분의 전략 분류 연구들이 설문 응답자들의 주관적 판단 또는 대표적 전략적 행위에 대한 선택에 의 하여 분류되었지만, 본 연구에서는 마케팅 전략, 연구개발 전략, 품질 향상 전략 등 구체적이고 실증적 측정을 기반 으로 기업의 전략적 판단 및 행동행위에 대한 분류를 하였고 궁극적으로 성과와의 관련성을 알아보았다. 특히 1990 년대 후반 외환위기를 겪은 뒤 2001 년 설문 조사를 수행하여 수도권에 있는 상위 수출 중심 기업들의 경영 전략적 행태와 성과간의 관계를 규명하였다. 이는 급격한 환경 변화에 적응하는 기업들의 전략적 행태를 인식하는데 도움을 줄 것이다. 연구 결과는 진취자 (prospector) 전략적 행위를 영위하는 기업 성과가 다른 전략적 행위 기업들보다 높은 성과를 보여 주었다.

Key Words : Strategy typology, Korean exporters performance, Strategic choice

\section{1. 서론}

Organizations need to attain competitive advantage for survival and sustainable growth especially in the turbulent environment. Generally speaking, survival and sustainable growth are attained by adopting new technologies and exploring new markets. Especially when organizational environment turns to be more turbulent, organizations need to develop their own strategic competencies by breeding their own distinctive competences and aligning with environmental requirements $[1,10,28]$.

The environmental factors that determine strategic behavior have been regarded as a dominant logic for organizational success[1,27]. Many strategic management researches found out that applications of different strategies by the change of the environment reshape organizational internal processes and eventually modify external market structure[3,6]. These behaviors increase the possibility of survival and success. Moreover, resistance to the change sometimes ended in the fatal

${ }^{*}$ Corresponding Author : Yum, Jihwan(jhyum@ $@$ bycu.ac.kr) 
results [4]. Differences in organizational strategies or capabilities to change the strategies have been recognized as a source of competitive advantage.

The issues of similarity among organizations also have received a great deal of attentions in strategic management and organizational theories $[8,10]$. Institutional power forces organizations to act similar way especially in the homogeneous environment. Quite a few of researchers have focused on the side of the similarity question, such as institutional theorists.

Where gaining a competitive advantage has becn a foremost objective for the organization, being the same (utilizing same strategy) may not be the appropriate behavior. Being different, exploring new strategies and new market in the blue ocean, an organization may benefit by less competition, ceteris paribus[16]. On the other hand, by being the same, an organization may benefit because it is recognized as legitimate, cetcris paribus $[10,17,23]$.

The long controversy has arrived at the temporal stable status thanks to globalization of modern cconomy. Globalization of economy cnforces organizations into two mutually exclusive directions. One way leads organizations being the same by adopting global standard in organizational management and production processes. The other way leads to being different pursuing organization specific competitive advantages. Researchers recognized the tension between the need for a firm to be different and the need for a firm to be the same almost in the same time and in the same market. Porac, Thomas, and Baden-Fuller (1989) suggested that strategists needed to balance on a competitive edge between simultaneous pressures to conform and to differentiate. Deephouse (1999) observed that strategic conformity reduces both competitive risk and opportunities for competitive advantage. Chen and Hambrick (1995) noted that theory and research on competitive conformity - its cause and effects should be a high priority for the field of strategy.

Korean companies have demonstrated phenomenal achievement in economic and technical performance for last two decades. Almost all of well known Korean companies have less then 40 year experiences in the market. Most companies' strategies were export oriented partly because of the relatively small domestic market size. From the beginning of the industrialization, export oriented strategy was one of the main theme for dominant market players in Korea. Export orientation strategy with lower cost structure was a dominant logic for most Korean managers. However, the phenomenal growth of industrial organizations faced serious threat in late 1990s. Asian financial crisis attacked and de-stabilized industrial backbone named as Chaebol, major conglomerates of Korea. For the relatively short period of time, Korean industries were forced to restructure and reshape by external program suggested by International Monetary Fund.

Considering the national specific situation, we need to evaluate the change of organizational strategy and structure both qualitatively and quantitatively. We will examine the implications that force organizations to react to the change of environment in different ways where past institutional power still exists to be the same. The study developed the research idea from the organizational adaptation in the fast environmental change situation. The data were gathered in 2001 when the Asian financial crisis has just cured. The research can demonstrate critical difference in strategic behavior from quantity orientation to quality orientation. The author adopt the theory of strategy typology as a reaction to the environment. Where stronger institutional forces exist, the difference in typology will not be related with the performance. In other words, the different strategy may not work for different performance. On the other hand, if the difference in typology is related with the performance difference, the heterogeneous strategy may be responsible to the performance gap.

\section{Strategy Typology Research}

The Miles and Snow's (1978) strategic typology defenders, prospectors, analyzers, and reactors - has generated a comparatively large amount of interest, investigation and support $[15,17]$. Although these studies have contributed significantly to the body of knowledge on strategic archetypes, there is nevertheless a need for further research. For instance, a review of strategy literature reveals an increasing level of in operationalization and measurement of strategy constructs [4].

Researches on the typology study lie in a wide variety of organizations and industries. Snow and Hrebiniak 
(1980) found that prospectors, analyzers, and defenders outperformed reactors in competitive but not highly regulated industries. Hambrick's (1983) data indicated that defenders consistently outperformed prospectors in profitability and cash flow but that prospectors outperformed defenders in market share gains in innovative industries. Zajac and Shortell (1989) discovered that prospector and analyzer hospitals outperformed defender hospitals in the rapidly changing health-care environment, results that Shortell, Morrison, and Friedman (1990) subsequently confirmed. The typology has also been used to differentiate tobacco firm's responses to environmental threats [18].

The Miles and Snow framework continues to be the most enduring strategy classification system available[9,15]. Despite ex post nature of the framework, a number of researchers have commented on the need for further empirical validation and testing of its underlying assumptions[7,35]. Those authors above noted the fact that the original Miles and Snow research was limited in the number of industries and the range of capabilities studied. They did not systematically study all the possible linkages between capabilities and strategic type, nor did they attempt to prove the validity of their typology across other industry types and foreign countries[9].

Miles and Snow (1978) proposed a relatively complex strategic typology interrelating organizational strategy, structure, and process variables within a theoretical framework of co-alignment. The theoretical foundations of Miles and Snow typology can be traced to Child's (1972) classic conceptualization of strategic choice. Miles and Snow proposed that organizations develop relatively enduring patterns of strategic behavior that actively co-align the organization with its environment. They viewed the 'adaptive cycle'characterizing this process as involving three imperative strategic 'problem and solution' sets.

The first one is an entrepreneurial problem set. It centers on the definition of an organization's product-market domain relating how the organization orients itself to the marketplace. This set is related with extra-organizational behavior. The questions related with this problem states: how does the organizations adapt to the change of market structure, customer tastes, and inter-organizational processes?

The second one is an engineering problem set. It focuses on the choice of technologies and processes to be used for production, service, and distribution. This set deals with core technologies of organizations and boundary spanning activities in technological arena.

The third one is an administrative problem set. It involves the selection, rationalization, and development of organizational structure and policy processes. It involves how the organization attempts to coordinate and implement its strategies. The main theme of an administrative set covers intra-organizational processes and achievement.

Each of the three problem sets involves multiple dimensions. However, this study mainly focuses the first problem set - an entrepreneurial problem. The entrepreneur problem set deals with extra-organizational problems and adaptive behaviors to the environment. We explored the distinction of strategy typology by asking how to solve entrepreneur problems. The characterization of strategy typologies can be expressed below.

A firm following a prospector strategy frequently adds to and changes its products and services, consistently attempting to be first in the market. Such a firm tends to stress innovation and flexibility in order to be able to respond quickly to changing market conditions.

An analyzer's strategy is to maintain a relativcly stable base of products and services while selectively moving into new areas with demonstrated promise. An analyzer tends to emphasize formal planning processes and tries to balance cost containment and efficiency with risk taking and innovation.

A defender's strategy is to offer a relatively stable set of services to defined markets, concerning on doing the best job possible in its area of expertise. It emphasizes tight control and continually looks for operating efficiencies to lower costs.

A reactor essentially lacks a consistent strategy. Its strategy has characteristics of each of the other type's strategies at different times and thus is difficult to categorize clearly.

A recent extensive review of research using the Miles and Snow typology found few attempts to assess the reliability or validity of its measures systematically[32]. Snow and Hambrick (1980) and Hambrick (1981) reported inter rater reliability assessments for expert raters ranging from .49 to .76 and Boeker (1989) reported reliabilities ranging from .57 to .82 . Hambrick (1983) also found that prospectors had a significantly higher ratio of 
research and development expenses relative to sales than defenders and a significantly higher ratio of marketing expenses relative to sales. Smith and colleagues (1986) found mixed support for the typology's validity. For the most part, researchers have inferred its validity from various qualitative observations without conducting further testing[32].

Most studies of strategy typology are pursued in relatively similar industries. The most strategic behavior researches control the industrial differences in order to maximize organizational performance differences while minimize other noise factors. However, the barrier of industrial membership has been weakened by development of technology, especially information and communication technology. Many researchers call this phenomenon as "digital convergence" [33]. We believe that the strategy typology research should get into inter-industrial perspective in order to integrate the concept of digital convergence. Moreover, the concept of digital convergence may bring significant effect for interpreting strategy typology in the information age.

Snow and Hambrick (1980) distinguish between four broad approaches for identifying strategy typology. The approaches to measure strategy typology are self typing, objective indicators, external assessment, and investigator inference. Conant ct. al., (1990) identified some missing rationales in four approaches. Based on their arguments, all four of these approaches have been employed in previous operationalizations of Miles and Snow's strategic typology. Some studies have relied on single-itcm scales when operationalizing what is recognized to be a multi-dimensional construct.

The use of single-item scale was also viewed appropriate, when they relate to a simple unidimensional construct, and can be measured with minimal measurement error. However, such scales are of limited value when they cannot adequately capture the broader concept being measured[21]. Hambrick (1983) proposed unidimensional approach for the strategy measurcment because strategy typology needs to bo captured in integrative nature and aspects. The paragraph approach requires that respondents read short paragraph-length deseriptions of each of the four strategic types, and then select only one type that best represents his or her organization. Even though the paragraph approach has been widely used, it can not be free from personal bias. The respondents' behavior may vary when they really make a decision and when they make an evaluation themselves.

The paragraph approach has been the most widely cmployed mcthod to operationalize Miles and Snow's strategic typology. In this context the paragraph approach to measuring Miles and Snow's strategic types employed in a number of previously referenced studies reveals a tendency to oversimplify the multi-dimensionality of archetype construct [7]. Typically, only two of three of strategic dimensions explicated in Miles and Snow's adaptive cycle model are considered and evaluated in this approach. Recent attempts have been made to operationalize and moasure Miles and Snow's strategic types using multi-item scales and multiple approaches. Although many researchers have advocated the usc of multiple approaches to opcrationalize and measure key operational constructs, few studies have employed multiple approaches to operationalize and measure Miles and Snow strategic typology. Furthermore, most previous research has tended to exclude the reactor type from the scope of analysis. The nced for multidimensional construct of strategic behavior is gaining a strong support for assessing organizational strategy. Furthermore, the rclationships with overall performance have not gained strong references yet.

\section{Research Design and Methodology}

We decided to employ integrative measurement using self typing, objective indicators, and investigator inference. Self typing is used for the questionnaire responses. Objective indicators arc used to measure respondents'strategic behavior such as market orientation, process definitions, and foreign business strategies and so on. However, the final judgment for organizations'strategic typology is based on the factor analysis which made composite components into a single strategy typology.

The advantage of this process lies in two folds. First, this process does not generate any bias for the respondents to be only one strategy typology. Responding various stratcgic process questions, the respondent's strategy typology is naturally declared. Sccond, the concept of strategy typology 
can employ some other distinguishing factors to differentiate strategy typology. For example, the global economy emphasizes the strategy for internationalization whether the organization is big or small. International business for the organization is not an option any more. Bringing respondents from the relatively homogeneous pool, Korean companies, we could generate intemational strategy as another aspect for strategy typology.

The questionnaire items were developed for strategy and market orientation of organization. The sample was selected from top 2,000 leading exporters located near Seoul, Korea. The respondents were mostly high level managers who understand statistical figures and organizational strategy. We interviewed top managers who are in charge of the department or business unit in person. However, some companies were interviewed with middle mangers when the top level managers were not available. The response rate was $22.5 \%$ (458 respondents).

[Table 1] Description of variables and construct used in the analysis

\begin{tabular}{|l|c|c|c|c|c|}
\hline & N & Min & Max & Mean & $\begin{array}{c}\text { Std. } \\
\text { Dev. }\end{array}$ \\
\hline Sales & 428 & 0.01 & 280 & 1.68 & 14.95 \\
\hline Profit & 430 & 1 & 7 & 4.25 & 1.22 \\
\hline Future_sales & 429 & 0 & 7 & 4.00 & 1.47 \\
\hline Prod_diversity & 427 & 1 & 7 & 5.00 & 1.46 \\
\hline New_prod_intro & 425 & 1 & 7 & 4.65 & 1.53 \\
\hline Adaptability & 427 & 1 & 5 & 2.22 & 1.17 \\
\hline Autonomy & 383 & 1 & 7 & 5.13 & 1.60 \\
\hline LnCpital & 406 & -2.3 & 10.7 & 2.78 & 2.23 \\
\hline LnEmployees & 429 & 0.69 & 10.8 & 4.43 & 1.86 \\
\hline Market_develCntry & 423 & 0 & 1 & 0.66 & 0.48 \\
\hline Price_ratio & 426 & 30 & 150 & 82.4 & 14.4 \\
\hline Own_brand_equity & 427 & 0 & 100 & 58.4 & 44.0 \\
\hline Quality & 427 & 14.3 & 250 & 85.5 & 17.6 \\
\hline Product_comptncy & 429 & 1 & 7 & 6.42 & 0.93 \\
\hline Price_comptncy & 430 & 2 & 7 & 6.32 & 0.92 \\
\hline Promotion_comptncy & 429 & 1 & 7 & 4.52 & 1.55 \\
\hline Place_comptncy & 427 & 1 & 7 & 4.94 & 1.61 \\
\hline HR_language_Know & 430 & 1 & 7 & 4.53 & 1.38 \\
\hline Defender & 378 & 0 & 1 & 0.31 & 0.46 \\
\hline Prospectors & 378 & 0 & 1 & 0.32 & 0.47 \\
\hline Reactors & 378 & 0 & 1 & 0.17 & 0.38 \\
\hline Analyzers & 378 & 0 & 1 & 0.19 & 0.39 \\
\hline Valid N (listwise) & 344 & & & & \\
\hline
\end{tabular}

Table 1 presents descriptive statistics for the research variables. Most variables were constituted in Likert style where figures such as sales, capital, number of employees were real and logged numbers, and price ratio and quality were relative figures. The last four strategy typologies were coded variables by the respondents' responses. The study employed SPSS for Windows.

We developed and modified questionnaire items in order to differentiate strategic typology. Based on the Miles and Snow's theory and multiple components from the responses, we applied cluster analysis in order to classify organizational strategy typology. Relatively long history of strategy typology research has shown that the four domains are moderately acceptable. However, the problem lies in measurement schema that can properly discern the strategy of organization. The study generated four clusters that are significantly different each other and four clusters successfully categorized four strategy typology. Table 2 shows the result of cluster analysis.

[Table 2] Typology of strategy of firms by Cluster Analysis

\begin{tabular}{|l|c|c|c|c|}
\hline & \multicolumn{4}{|c|}{ Cluster* $^{*}$} \\
\cline { 2 - 5 } & $\begin{array}{c}\text { Defender } \\
(\mathrm{n}=118)\end{array}$ & $\begin{array}{c}\text { Prospector } \\
(\mathrm{n}=122)\end{array}$ & $\begin{array}{c}\text { Reactor } \\
(\mathrm{n}=66)\end{array}$ & $\begin{array}{c}\text { Analyzer } \\
(\mathrm{n}=72)\end{array}$ \\
\hline Prod_diversity & 4.13 & 6.25 & 3.64 & 5.68 \\
\hline New_prod_intro & 3.62 & 5.95 & 3.18 & 5.50 \\
\hline Adapt & 2.24 & 1.65 & 3.05 & 2.39 \\
\hline Atonomy & 6.03 & 6.19 & 3.24 & 3.68 \\
\hline
\end{tabular}

* significantly different 4 clusters was attained.

The cluster analysis shows four distinguished aspects for each strategy typology. The aspects are product diversity, new product introduction, adaptation, and autonomy. Product diversity refers that the organization's strategic intent to provide various versions of the product. New product introduction means the organization's ability to introduce new product in a short period of time. Adaptability denotes the organization's effort to modify the product for the various markets. Autonomy indicates the level of decentralized decision making structure.

Table 3 shows frequencies of strategy typology from the data. The number of responses shows that defender and prospector are similar and reactor and analyzer are also similar. 
[Table 3] Percentage of each strategic typology of Korean exporting companies

\begin{tabular}{|l|r|r|r|}
\hline & $\begin{array}{c}\text { Valid } \\
\text { Frequency }\end{array}$ & \multicolumn{2}{|c|}{ Cumulative Percent } \\
\hline Defender & 118 & 31.2 & 31.2 \\
\hline Prospector & 122 & 32.3 & 63.5 \\
\hline Reactor & 66 & 17.5 & 81.0 \\
\hline Analyzer & 72 & 19.0 & 100.0 \\
\hline Total & 378 & 100.0 & \\
\hline
\end{tabular}

We developed the rational that the relationship between organizational strategy typology and organizational performance should be somewhat significant. As most strategy typology researches have not concluded, using relatively homogeneous sample (Korcan leading exporters) is expected to generate significant result.

First, we utilized ANOVA in order to investigate the performance relationship with strategy typology. We devised two components for performance, such as profit and sales. The rationales to regard this way are two folds. First, the sample is relatively homogeneous. The leading exporters in Korea are relatively stable in their market position and their strategy has not been changed very much. Second, compared to domestic business oriented organizations, cxporters need to concentrate their strategy for increasing sale and improving profit in relatively in short period of time. The government policy and incentives lead relatively narrow scope for foreign business Table 4 presents the relationships among dependent variables and strategy typologies. The analysis shows only profit demonstrates significant relationship with strategy typology.

[Table 4] ANOVA

\begin{tabular}{|c|c|c|c|c|c|c|}
\hline & & $\begin{array}{l}\text { Sum of } \\
\text { Squares }\end{array}$ & df & $\begin{array}{l}\text { Mean } \\
\text { Square }\end{array}$ & $F$ & Sig. \\
\hline \multirow{3}{*}{ sales } & $\begin{array}{c}\text { Between } \\
\text { Groups }\end{array}$ & 955.3 & 3 & 318.5 & 1.3 & 0.289 \\
\hline & $\begin{array}{l}\text { Within } \\
\text { Groups }\end{array}$ & 94350.5 & 372 & 253.6 & & \\
\hline & Total & 95305.8 & 375 & & & \\
\hline \multirow{3}{*}{ profit } & $\begin{array}{c}\text { Between } \\
\text { Groups }\end{array}$ & 26.3 & 3 & 8.8 & 5.9 & 0.001 \\
\hline & $\begin{array}{l}\text { Within } \\
\text { Groups }\end{array}$ & 557.2 & 374 & 1.5 & & \\
\hline & Total & 583.6 & 377 & & & \\
\hline
\end{tabular}

Based on the ANOVA result, we decided to investigate the most contributing factor with organizational performance, in other words the relationships with profit.

\section{Hypotheses}

The export market has been defined as product competitiveness (Porter, 1986). The price competitiveness or quality advantage may lcad to the superior performance. Considering strategy typology, product competitiveness may $b c$ independent if we consider relatively short period of time. If we consider longitudinal standpoint, strategy typology and product competitiveness may be strongly correlated. Based on this short term perspective, we developed hypothesis 1 below:

H1: Organizations that have higher level of product competitiveness will have higher rate of profit.

As we investigated middle managers, their time frame could not be long enough. In the cross sectional research, but not in the longitudinal research, organizational profit is strongly related with marketing strategy. Rigorous marketing strategy tends to improve short term profit. However, strong marketing strategy without improving competitive edge eventually erodes the initial advantage. We considered marketing strategy as a significant factor related with profit. Based on this argument, hypothesis 2 was developed:

H2: Organizations that have strong marketing strategy will have higher rate of profit,

In the global business, the most important factor for competitiveness has been considered as human resources (Peng \& Luo, 2000). Where technical resources or institutional advantages can be casily eroded, human resources are hard to imitate and to substitute. Organizational human resource is the only source of sustainable competitive advantage. Based on this argument, we developed hypothesis 3 :

H3: Organizations that have higher level of human resource will have higher rate of profit.

The argument of strategy typology is sometimes criticized as ex post description. This means the rather than managerial decisions and actions, organizations, decision making habits are articulated afterward. In order to minimize this critic, we evaluated the strategy typology based on respondents' questionnaire items so called 'integrative measurement using self typing, objective 
indicators, and investigator inference.' We believe that strategy typology and organizational performance may have somewhat stringent relationship. Based on this argument, we developed hypothesis 4 :

H4: Organizations that have different strategy typology will have different rate of profit.

[Table 5] Results of Regression Analysis

\begin{tabular}{|l|c|c|c|c|c|}
\hline Variables & $\begin{array}{l}\text { Basic } \\
\text { Mode1 }\end{array}$ & $\begin{array}{l}\text { Product } \\
\text { Competit } \\
\text { iveness }\end{array}$ & $\begin{array}{l}\text { Markcting } \\
\text { Strategy }\end{array}$ & $\begin{array}{l}\text { Human } \\
\text { Resource }\end{array}$ & $\begin{array}{l}\text { Strategy } \\
\text { Typology }\end{array}$ \\
\hline Basic Model & & & & & \\
\hline LnCpital & .120 & .085 & .092 & .078 & .065 \\
\hline LnEmployees & -.012 & -.022 & -.030 & -.018 &. .038 \\
\hline Market_develCntry & $.118^{*}$ & $.140^{* * *}$ & $.142^{* * *}$ & $.149^{* * *}$ & $.143^{*}$ \\
\hline Product & & & & & \\
\hline Pompetitiveness & & & & & \\
\hline Price_ratio & & .018 & .024 & .023 & -.015 \\
\hline Qwit_brand_equity & & .059 & .052 & .061 & .052 \\
\hline Marketing Strategy & & & & & \\
\hline Product_comptncy & & & .044 & .025 & -.040 \\
\hline Price_comptncy & & & -.036 & -.033 & -.018 \\
\hline Promotion_comptncy & & & .100 & .092 & .088 \\
\hline Place_comptncy & & & .003 & -.009 & -.023 \\
\hline Human Resource & & & & & \\
\hline HR_language_Know & & & & .095 & .059 \\
\hline Strategy Typology & & & & & \\
\hline Defender & & & & & $.190^{* * *}$ \\
\hline Reactor & & & & & $.179^{* * *}$ \\
\hline Analyzer & & & & & -.057 \\
\hline $\mathrm{R}^{2}$ & & .029 & .014 & .008 & .034 \\
\hline $\mathrm{R}^{2}$ Change & & $.050^{* *}$ & .069 & .077 & .111 \\
\hline
\end{tabular}

$\S$ The reference group in the strategy typology is prospector. * $\mathrm{p}<.05,{ }^{* *} \mathrm{p}<.01,{ }^{* * *} \mathrm{p}<.001$

\section{Results}

The basic model includes the size of the organization such as capital range and number of employees and target market. Capital and number of employees were recoded with natural $\log$ because the value is high. Target market is distinguished by the main foreign market is either less developed countries or developed countries. The strategic orientation may vary by the target market with organizational demographic variables. If the organization emphasizes developed countries for its target market, the strategy should be different from the organizations for less developed countries. The strategic orientation for different level of countries will also end different level of profitability by dealing with more value added products. The basic model results show that target market orientation has a significant relationship with the profitability. Other factors that reflect the size of the organization such as capital and number of employces did not show significant relationship.

The second model, adding variables concerning product competitiveness factors show that only quality is the significant predictor for profitability. $\mathrm{R}$ square change was .029. Price ratio and brand equity did not have significant relationship with organizational profitability.

The third model added marketing strategy resulted that no significant relationship with the level of profitability. $\mathrm{R}$ square change was .014 .

The fourth model adding organizational human resource also resulted in no significant relation with performance. $R$ square change was .008. Human resource in this study measured organizational members'foreign language capability.

The final model adding strategic typology resulted in significant relationship with organizational performance. Prospector strategy is significantly outperformed other strategy organizations. We based prospector as a reference group to investigate significant relationship. Many strategy typology researches concluded that prospector strategy demonstrated significantly higher level of performance[ 7,30$]$. Based on the past research results, we based prospector as a reference strategy. $\mathrm{R}$ square change was .034 and $\mathrm{R}$ square was .011 .

The $\mathrm{R}^{2}$ and the change value was not our main concern but the $\mathrm{p}$ value of variables was our interest. The result shows statistically significant explanation about the relationship among strategy typologies.

\section{Conclusions}

The study employed Miles and Snow's strategy typology for evaluating organizational performance of Korean leading exporters. The results demonstrated that prospectors outperformed other strategies. 
This study contributed to the academia and practitioners in three perspectives. First, strategy typology study has pushed respondents to be only one sct of strategic behavior. Other options were not available. In the information age, fast changing and very turbulent enviromment urges organizations to be fast adaptors. Strategy lypology research should adopt this phenomenon. Based on organizations" various strategic behavior, researchers could apply triangulation to assign organizations' representative strategic behavior.

Second, not many studies are done for Korean exporters recently. Entering into information age, the Korean exporters showed structural change from utilizing cheap labor to creating new technology and market such as MP3 players and multi functional cellular phones. In. the transitory environment, this study will light a way that organizations should follow.

Finally, this study shed a light to both academia and industry analysis practitioners. Two strategic options in global enviromment, being the same or being different, have not met any conclusive remark. Still some researcher and practitioners emphasize organization specific factors as the only source of sustainable advantage. Others start to consider revitalized institutional power considering fast spreading technology and standard setting environment. Keeping organization specific advantage might lose whole market abruptly as Sony's Beta max video cassette disappeared. Our study shed a clue for strategic options such a turbulent digital business arena. Organizations need to use bold compctitive position with maximum flexibility. Traditional marketing strategy may not appropriate. Emphasizing quality in the arena, bold prospectors will survive in the global marketing arena.

\section{References}

[1] Ansoff, 1., "The emerging paradigm of strategic behavior." Strategic Management Journal 8: 501-515. 1987.

[2] Boeker, W., "Strategic Change: The Effects of Founding and History."Strategic Change: 32(3): 489-515, 1989.

[3] Bogner, W. C., \& Thomas, H. The role of competitive groups in strategy formulation: A dynamic integration of two competing models. Journal of Management Sindies, $30(1), 51-67,1993$.
[4] Bourgeois, I., L. J., "Strategy and environment: A conceptual integration." Academy of Management Review, 5(1), 25-39. 1980.

[5] Chen, M. J. and D. C. Hambrick, "Speed, stealth, and selective attack: How small firms differ from large firms in competitive behavior." Academy of Management Journal 38: 453-482. 1995.

[6] Child, J., Organizational structure, environment and performance: The role of strategic choice. Sociology, $6,1-22$.

[7] Conant, J. S., Mokwa, M. P., \& Varadarajan, P. R. Strategic types, distinctive marketing competencies and organizational performance: A multiple measures-based study. Strategic Management Journal, 11, 365-383, 1990.

[8] Deephouse, D. L., "To be different, or to be the same? It's a question (and theory) of strategic balance." Strategic Management Joumal, 20(2): 147-66, 1999.

[9] Desarbo, W. S., C. A. D. Benedetto, et al., "Revisiting the Miles and Snow strategic framework: Uncovering interrelationships between strategic types, capabilities, environmental uncertainty, and firm performance." Strategic Management Joumal 26: 47-74, 2005.

[10] DiMaggio, P. J. and. Powell, W. W., "The Iron cage revisited: Institutional isomorphism and collective rationality in organizational fields." American Sociological Revicw 48: 147-160, 1983.

[11] Dobni, B. C., \& Luffman, G., Market orientation and market strategy profiling: An empirical test of environment-behavior-action coalignment and its performance implications. Management Decision, $38(8), 503-, 2000$.

[12] Fiegenbaum, A., Hart, S, \& Shendel, D. Strategic reference point theory. Strategic Management Joumal, $17,219-235,1996$.

[13] Grant, R. M., Strategic planning in a turbulent environment: Evidence from the oil majors. Strategic Management Journal, 24, 491-517, 2003.

[14] Gupta, Y. P., Karimi, J., \& Somers, T. M., Alignment of a Firm's Competitive Strategy and Information Technology Management Sophistication: The Missing Link. IEEE Transactions on Engineering Management, 44(4), 399.412, 1997.

[15] Hambrick, D. C., "Some tests of the effectiveness and functional attributes of Miles and Snow's strategic types." Academy of Management Joumal 26(1): 5-26, 1983.

[16] Kim, W. \& Mauborgne, R., "Blue ocean strategy" 
Harvard Business Press, 2005.

[17] Meyer, J. W. and B. Rowan, "Institutional organizations: formal structure as myth and ceremony." American Joumal of Sociology 83: 340-63, 1977.

[18] Miles, R. H. and K. S. Cameron, Coffin nails and corporate strategies. Englewood Cliffs, N.J., Prentice-Hall, 1982.

[19] Miles, R. E., \& Snow, C. C. "Organizational strategy, structure and process" New York: McGrow-Hill, 1978.

[20] Miles, R. E., \& Snow, C. C., Organizations: New concepts for new forms. California Management Review, 28(3), 62-73, 1986.

[21] Nunnally, J. C., Psychometric theory. New York, McGraw-Hill, 1978.

[22] Peng, M. W., \& Luo, Y., Managerial ties and firm performance in a transition economy: The nature of a micro-macro link. Academy of Management Joumal. 43(3), 486-501, 2000.

[23] Pfeffer, J. and G. R. Salancik, The external control of organizations: A resource dependence perspective. New York, Harper \& Row, 1978.

[24] Porac, J., H. Thomas, et al., "Competitive Groups as Cognitive Communities." Journal of Management Studies 26(4): 397-416, 1989.

[25] Porter, M. E., "Changing patterns of international competition." California Management Review 28(2): 9-40, 1986.

[26] Rowan, W. M. B., "Institutional organizations: formal structure as myth and ceremony." American Journal of Sociology 83: 340-63, 1977.

[27] Schendel, D., "Strategy futures: What's left to worry about?" Advances in Strategic Management 11B: 143-188, 1995.

[28] Selznik, P., "Foundations of the theory of organization." American Sociological Review 13: 25-35, 1948.

[29] Selznik, P., Leadership in administration. New York, Harper \& Row, 1958.

[30] Shortell, S. M., \& Zajac, E. J., Perceptual and archival measures of Miles and Snow's strategic types: A comprehensive assessment of reliability and validity. Academy of management Journal, 1990.

[31] Shortell, S. M., E. M. Morrison, et al., Strategic Choices for American Hospitals. San Francisco, Jossey-Bass, 1990.

[32] Snow, C. C. and L. Hrebiniak, "Strategy, Distinctive Competence, and Organizational Performance." Administrative Science Quarterly 25: 317-335, 1980.

[33] Yun. Jong-Yong, "Beyond the knowledge economy"
Global Agenda, 4(1) 136-138, 2006

[34] Zajac, E. J. and M. H. Bazerman, "Blind spots in industry and competitor analysis: Implications of interfirm (MIS) perceptions for strategic decisions." Academy of Management Review 16(1): 37-56, 1991.

[35] Zajac, E. J. and S. M. Shortell, "Changing Generic Strategies: Likelihood, Direction, and Performance Implications." Strategic Management Journal 10(5): 413-30, 1989.

Yum, Jihwan

[Regular member]

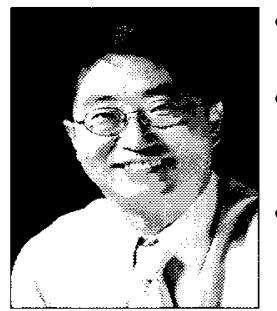

- May, 1994 : University of Nebraska, Lincoln MA (Management)

- Feb. 2000 : US International University DBA (Strategic Management)

- Jan. $2001 \sim$ Current : Associate Professor at Hanyang Cyber University

<관심분야>

Information Technology Strategy, Knowledge Management, Cyber Education 